\title{
The ERASMUS experience and its capacitating potential: Analysis of adaptive capabilities
}

\author{
María-Jesús Martínez-Usarralde ${ }^{\mathrm{a}, *}$, Juan Murillo Pausáb ${ }^{\text {, Rafaela García-López }}{ }^{\mathrm{c}, 1}$ \\ a Departamento de Educación Comparada e Historia de la Educación, Facultad de Filosofía y Ciencias de la Educación, Avda. Blasco Ibáñez, 30,46021 \\ Valencia, Spain

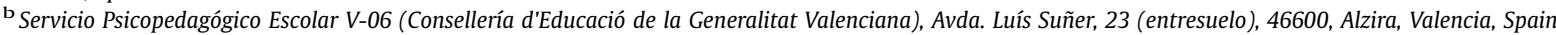

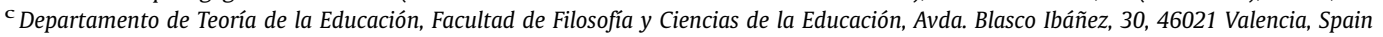

\section{A R T I C L E I N F O}

Article history:

Received 29 January 2016

Received in revised form 21 December 2016

Accepted 5 January 2017

\section{Keywords:}

Human development

Capabilities

Higher education

Student mobility

ERASMUS

\section{A B S T R A C T}

This analysis takes as its focus the Erasmus experience and seeks to obtain information about how it contributes to human development in accordance with the capabilities approach of Amartya Sen and Marta Nussbaum. By way of a qualitative research proposal, and with the support of NVIVO 10 software, evidence is found of the "capacitating potential" of the aforementioned European Union mobility programme. This evidence is detailed through qualitative data-in this case regarding "adaptive capabilities", representing one of six areas of study pursued in this investigation.

(C) 2017 Elsevier Ltd. All rights reserved.

\section{Introduction}

This article presents a section of the results that have been obtained from an investigation into the Erasmus study scheme in Spain. $^{2}$ This initiative is based on a document review from the origins of the programme up to the present day, considering documentation from the area of influence and the agencies involved, and looking at the future prospects of this proposal for mobility; making it possible to approach the object of study in question.

Following on from the above, a theoretical foundation has been developed, which has culminated in a specific conceptual map of human development based on capabilities. This map includes its own proposal of six major areas of capabilities, integrating the theories of authors such as Sen $(1980,1995,1997,1999 a, 1999 b$, 2003, 2006, 2011), Nussbaum (1997, 1998, 2000, 2011, 2015) and

\footnotetext{
* Corresponding author.

E-mail addresses: m.jesus.martinez@uv.es (M.-J. Martínez-Usarralde), murillo-juapau@gva.es (J.M. Pausá).

1 Deceased.

2 This article is framed in the context of the programme I+D+I ref. EDU201236739, "Equidad y movilidad universitaria en el nuevo marco del Espacio Europeo de Educación Superior: análisis del índice de elegibilidad ERASMUS a la luz de factores socioeconómicos" (2013-2015).
}

both (1993). However, our map attempts to establish itself as a more mixed, multidisciplinary and multidimensional vision. To this end, we have reviewed a variety of initiatives which represent, simultaneously, different paths towards the application of said theory to specific research experiences in the area of education (Boni et al., 2010; Boni and Walker, 2013; Cejudo, 2006; DeCesare, 2014; Deneulin and Townsend, 2006; Flores, 2002; Mutanga, 2014; Sastre et al., 2012; Vaughan and Walker, 2012).

Proceeding from the aforementioned map, a specific category system has been developed and is now in the research phase. This system responds to the need for a tool which enables an assessment of the expansion of capabilities as a consequence of the Erasmus experience, and it establishes a qualitative research design for obtaining the relevant information. Based on this assessment, development itself can be measured (Sen, 1999b). Faced with the question "Is the Erasmus programme favourable to human development?" an affirmative answer will be subject to the expansion of freedoms by way of the capabilities and functionings ${ }^{3}$ that those involved associate with said experience.

\footnotetext{
${ }^{3}$ These concepts are discussed in-depth in works such as 'Development and freedom', 'Well-being, justice and market' by Sen; 'The quality of life' by Sen and Nussbaum; and 'Women and human development' by Nussbaum. References to these works can be found in the bibliography.
} 


\subsection{The Erasmus Programme. Contextualization for reading in terms of capabilities}

The Erasmus programme has become the most significant programme for European cooperation in Higher Education (and the promotion of mobility). It promises to play an ever-greater role in the future, thus continuing its trend of growth and liberalization. Due to this upward trend, some had anticipated its recordbreaking figure of 3 million students during the period 2012-2013. Spain stands out for its leading role both as a contributor and a receiver of students (Valle and Garrido, 2014). This fact has been confirmed recently by the European Commission (2014) in a report about the global impact of the programme.

Moreover, the economic crisis is reinforcing European interest in education. Education, particularly higher education, is seen as being one of the most important areas of cooperation in seeking a way out of the economic crisis (European Commission, 2010; European Council, 2013; EURYDICE, 2012). ${ }^{4}$ This trend reinforces the role of the Erasmus programme and boosts its aforementioned growth.

In addition, based on the conclusions of the Lisbon European Council (2010), in which the horizon set for 2010 was centred on converting the European brand into the most competitive and dynamic knowledge-based economy in the world, there begins a predisposition to focus attention on the economic interests attributed to the effects of the programme, pushing social objectives into the background (Valle, 2004). The evolution of these economic interests by Erasmus promotors has determined the latest regulations and this, in turn, has determined the focus of attention as regards the evaluation of the programme's benefits.

Through certain studies it can also be concluded that the Erasmus programme has a positive impact on the capabilities and skills of participants. In particular, we can speak of capabilities and benefits related to an increase in employability (European Commission, 2014) as well as benefits related to the acquisition of skills and to personal growth (Aguaded and Pozo, 2009; Alfranseder et al., 2012; Fernández, 2010; Fernández et al., 2009; Pineda et al., 2007; Pozo, 2011).

Finally, we find other elements which centre on the debate about a public initiative such as this one. For example, some studies show evidence of inequality as regards the participants' capacity for choice in scholarships-a fact that correlates with the asymmetry detected with regards to groups of participants and the destinations chosen for mobility (Valle and Garrido, 2009).

In conclusion, it follows that we find ourselves before an educational initiative that is not being analysed in terms of capabilities. However, from the analyses and from current discussions about the initiative, it is possible to locate signs of constraint and potential from a perspective of human development. This fact has led to a focus of attention on Erasmus with the aim of obtaining evidence about the benefits of the programme from another point of view: its contribution to the expansion of capabilities.

\subsection{Human development and a focus on the increase of capabilities}

In the current context it is possible to locate consolidated criticisms of the belief that the growth of GDP (Gross Domestic

\footnotetext{
${ }^{4}$ These references are included as specific examples of reports in the context of the European Union which affect the question posed. It is important to note also that there are many more contemporary documents in which this trend is evident, both from the European Commission and other EU bodies.
}

Product $)^{5}$ of nations alone represents their development. Factors such as human development set themselves up as alternatives to this reductionist vision-in this case placing the main focus of attention on the results of global policies regarding the lives of people (all people). From the perspective of Sen and Nussbaum as regards the focus of capabilities, the issue of the representativeness of GDP in development would have to be asked the following question: But are the freedoms of citizens (all citizens) really increasing in terms of real possibilities (capabilities) for their own life projects?

Faced with the above question, and taking the aforementioned approach, a capabilities model based on this vision of development should concern itself both with the expansion of the freedoms of citizens as a means of achieving the life they desire, and with increasing freedoms generally because of the value they provide the citizenship, regardless of their instrumental character. In response to this demand, Sen (1999a) proposes that we focus our attention-in terms of evaluating development (attributed in this case to the Erasmus experience)-on the expansion of capabilities (essentially), but also (although in a secondary form) on functionings. Sen defines and qualifies these concepts as follows:

"Functionings represent parts of the state of a person-in particular the various things that he or she manages to do, or be, in life. The capability of a person reflects the alternative combinations of functionings the person can achieve, and from which he or she can choose one collection" (Sen and Nussbaum, 1993, p. 55).

The reason for focussing attention on the expansion of capabilities is connected to the leading role of freedom within this approach (Clark and Fennell, 2014; Nebel et al., 2014). It is about increasing the opportunities for people to progress down the paths that they decide to take, without predefining functionings as indicators of development itself (Ibrahim and Tiwari, 2014). This idea leads to the consideration that functionings must be unpredictable since they depend on the decisions of the people who develop them. But even so, the value that functionings can have as indicators should not be overlooked, even if they play a secondary role as evidence of said choices. In fact, capabilities will manifest themselves as an increase in real opportunities in different fields, thus representing the widening of options that a person has at his or her disposal when faced with decisions involving the different functionings (Hans-Uwe and Schafer, 2014; Walker, 2012).

From this point onwards, as anticipated, a theoretical model of human development was created for the investigation. This model has six major areas which, in turn, integrate a variety of specific capabilities (Fig. 1). Said model is presented as an open and unfinished proposal that is nevertheless useful in the task of fixing specific indicators of observation. For the creation of this model we returned to the most fundamental concepts of Sen (1999b), translating said contributions, together with other key and contemporary concepts in education, like the concept of collective intelligence (Marina, 2008, 2010) or the contributions of mirror neurons (Iacoboni, 2009). In essence, a comprehensive proposal of areas of capabilities was developed (something not found in the contributions of Sen). This took inspiration from lists such as Nussbaum's Central Capabilities, but without claiming the shared (universal) minimums proposed by that author, instead putting together a strategy for locating areas to be observed, based on the central idea shared by both authors: to focus attention on the

\footnotetext{
5 The index currently in use and considered the most significant for assessing the economic growth and status of nations.
} 


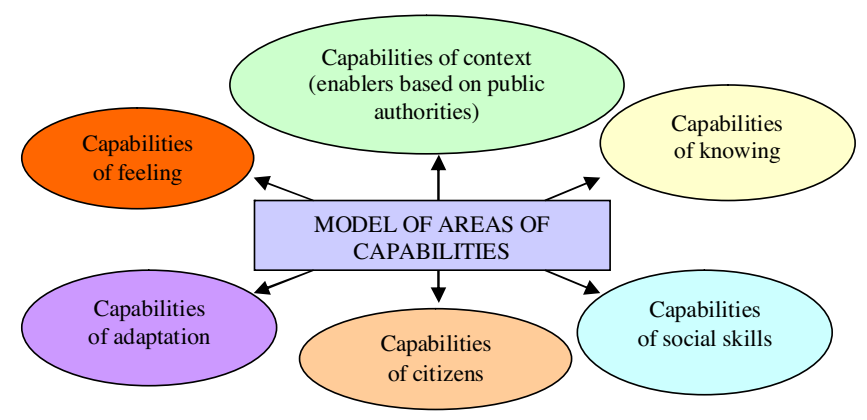

Fig. 1. Theoretical proposal of areas of capabilities. Source: prepared by the authors.

expansion of people's capabilities in order to observe authentic development.

In Fig. 1 you can see the areas of general capabilities which represent the initial classification-areas that are later developed in accordance with the framework in which the model lies.

With respect to the contribution that is made here to the discussion within the framework of the capabilities approach, three fundamental features can be highlighted. Firstly, there is an intention to organize a specific proposal by recovering the main theoretical contributions of Sen, while providing a complimentary vision which permits the integration of many other theoretical initiatives. Secondly, concepts are incorporated which, a priori, are not typical in discussions of this approach, with the aim of providing a multidimensional view to the proposal from a pedagogical perspective. Thirdly, this proposal of areas aims to overcome fundamental criticisms of the approach, such as its lack of flexibility (attributed occasionally to the contributions which set specific capabilities); its lack of precision as regards indicators (attributed to Sen, for example); and the excessive individualism of the approach itself (which neglects the dimension of the person as a social being). ${ }^{6}$

On another level of precision, and following on from the previous proposal, a categorical system is developed for gathering information. This system is based on both a deductive approach (centring attention principally on the pre-established capabilities as defined by theoretical approaches and the model itself) and an inductive approach, given that new capabilities emerge (including some functionings) from the analysis of the information itself, contributing to the map of developments attributed to the Erasmus programme.

Displayed in this article are results relating to one of six areas of capabilities which have been constructed by means of the initial theoretical process described in previous paragraphs. The area examined is that of "capabilities of adaptation" (Fig. 2).

\section{Design and methodology of the investigation}

As indicated, the intention has been to obtain evidence about the benefits and effects of the Erasmus programme via the perceptions of those who have participated in the programme as students or been involved in it in some way. In order to design an investigation that would adapt as much to these intentions as to the units of analysis that were intended to be addressed and to the content analysis technique, a wide variety of investigations and authors have served as useful guides: Alonso et al. (2009); ÁlvarezGayou (2003); Barbour (2013); Denzin and Lincoln (2012); Huber

\footnotetext{
${ }^{6}$ Contributions and/or criticisms fundamental to the present question can be found in authors such as Dubois (2008), Deneulin and Townsend (2006), Barone and Mella (2003).
}

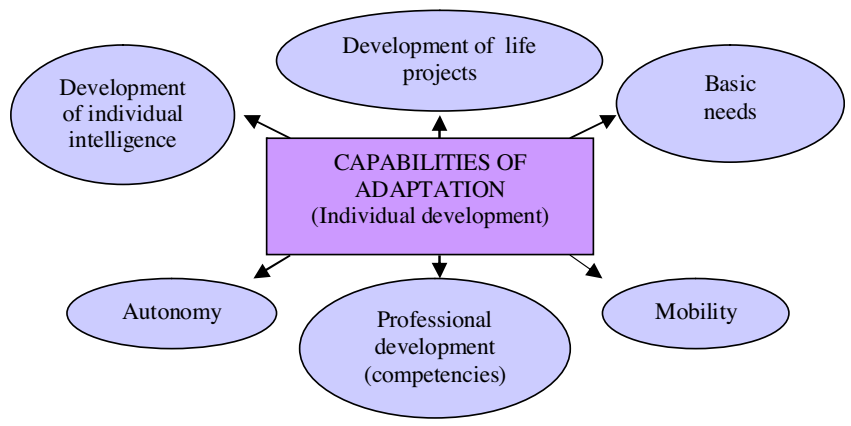

Fig. 2. Area of "capabilities of adaptation".

Source: prepared by the authors.

et al. (2001); Piñuel (2002), Piñuel and Gaitan (2003, 2004); Serbia (2007); Sommer and Sommer (1997); Strauss and Corbin (1990); Valdemoro et al. (2011); Weber (1990).

Specifically, a mixed approach has been undertaken, integrating both a vertical and transversal design (Piñuel, 2002). References to the benefits of the Erasmus experience have been collected, while various agents, forming independent groups representing different points of view on the phenomenon, have been analysed within the same historical moment (Piñuel, 2002). In this case, the different agents are made up of former scholarship students, programme coordinators, promoting organizations and companies interested in Erasmus. Here, the samples of the textual corpus are texts referring to the programme taken from three official EU websites ${ }^{7}$; five websites of Spanish universities participating in Erasmus ${ }^{8} ; 21$ articles selected from the Recruiting Erasmus ${ }^{9}$ magazine (20122013); and the speeches of 10 programme coordinators and 20 former Erasmus scholarship students (using open questionnaires). ${ }^{10}$ In this way, the postures adopted are represented by the different agents concerned, with their appreciation of the benefits attributed to the Erasmus experience. The time period coincides with the timeframe selected for collecting the sample (information published or emitted during the 2012-2013 and 2013-2014 courses, but which, since it involves an examination of the results observed during the experience, represents a view of the phenomenon in its last two versions: Erasmus in Socrates II and Erasmus in the Lifelong Learning Programme). ${ }^{11}$

It is also worth noting that an asymmetric design has been established. It is not possible to place information generated by investigators via open questionnaires on the same plane as information collected from texts which have been prepared

\footnotetext{
78 websites of official EU institutions were reviewed. Texts from 3 of these were finally selected to be representative of the total information reviewed.

${ }^{8}$ The websites of the 20 Spanish universities with the highest level of participation in the Erasmus programme (according to SEPIE: Spanish Service for the Internationalization of Education) were reviewed. Of these 20 websites, 5 which displayed information (regarding Erasmus scholarships) that was both relevant and representative of the total reviewed were selected.

${ }^{9}$ Recruiting Erasmus is a business initiative (promoted by the company Peoplematters), which unites different companies in the mission of recruiting students or former students with experiences of mobility through Erasmus or similar schemes. The proposal is supported by a magazine (with the same name) in which articles are printed relating the Erasmus experience to certain capabilities relevant to the workplace.

${ }^{10}$ The open-ended format of questionnaire (carried out online) was chosen due to the relocation of participants. However, given the nature of the research, clarifications were made via email to those participants who requested it (during research implementation). The questionnaire in this instance serves to prompt discourse from participants (spontaneous benefits as well as benefits that are based on areas of the described model of capabilities). Therefore, although we talk about a questionnaire, we have followed interview criteria that fit within the framework of a qualitative investigation (Barbour, 2013).

11 Period of regulation of the Erasmus programme between 2000 and 2013.
} 


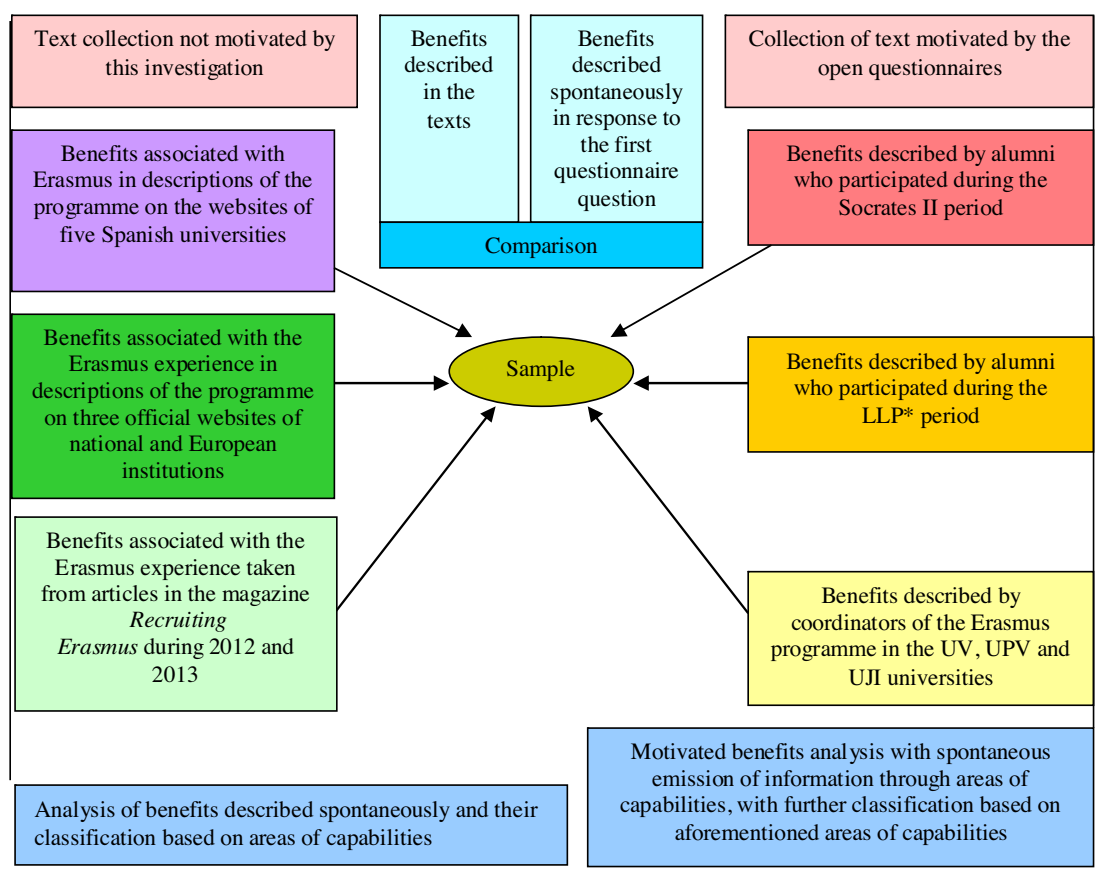

Fig. 3. Organization of the sample based on text type and collection procedure *LLP: Lifelong Learning Programme.

Source: prepared by the authors.

previously in their contextual areas. Fig. 3 displays this distribution graphically.

To undertake some comparisons about the benefits targeted spontaneously ${ }^{12}$ among different agents, an initial question was incorporated into the questionnaire, asking participants to state which benefits resulting from their Erasmus experience they considered the most significant. In this case we can establish comparisons between the meanings of texts and the discourse of the first question of the questionnaire.

Finally, a triangular design was established, referring partly to the collection and comparison of different perspectives on the same situation (Piñuel, 2002). Here, said triangulation responds to the interest in approaching an in-depth understanding of the phenomenon in question (obtaining different views from different types of information and agents regarding a single phenomenon) (Denzin and Lincoln, 2012). This triangular design also reflects the need to combine different techniques for validating the data by way of contrast, gathering information from a documentary review of texts published in a variety of formats and contexts, and via the implementation of open-ended questionnaires targeted at diverse groups (Piñuel, 2002).

As regards reliability and validity-aside from the aforementioned triangulation-a low level of categorization inference has been respected. In addition, as discussed below, we have used the NVIVO 10 programme, which allows the textual references to be kept at all times. Furthermore, fixed text selection criteria have been established in each category; a prior theoretical study has been carried out; and an in-depth, in-context analysis of the phenomenon under study has been implemented in order to prepare the sample and construct the initial categorical system. Finally, the verifiability of the information is assured (the sample is

\footnotetext{
12 The word 'spontaneous' here refers to its definition as voluntary or via an inner impulse. In other words, this adjective is used to refer to information which was not prompted by the investigators of this project in the current investigation and/or which has been expressed by the agents themselves without previous guidance regarding the type of information requested.
}

comprised of information published in magazines and on webpages, as well as of information from online questionnaires completed by programme participants. Textual references are always locatable) (Demerath, 2006).

With respect to the collection of the sample, criteria based on qualitative research models have been taken into account (ÁlvarezGayou, 2003; Serbia, 2007). This means that the sample has been established in accordance with the conclusions of our prior analysis of the programme's development; with agents, information sources and the methodology of sample collection being selected after an in-depth analysis of the subject matter and its contextual situation. Secondly, criteria have also been set in accordance with the capabilities approach theory. For example, in the case of questionnaires involving former scholarship students, selection criteria were designed to ensure a representational balance of candidates with regards the following: duration (for a variety of academic courses and over the two chosen periods); sex (with equilibrium between candidates); socio-economic origin (with medium-low and medium-high sources represented); field of studies (from five branches: Engineering and Architecture, Health Science, Arts and Humanities, Social and Legal Sciences, and Science); destination country (with equilibrium between highly represented countries-Italy, the United Kingdom, Germany, France-and underrepresented countries like Belgium, the Czech Republic, Portugal, Poland, Sweden and Iceland); university of origin (with representatives from 11 different Spanish universities); area of origin (rural/urban) and current employment status (employed in a field related to initial education/employed in a field unrelated to initial education/unemployed).

Finally, with regards to the computer tool utilized, the NVIVO 10 programme is a piece of qualitative analysis software (Kolenic, 2013). It relies on the logic of "grounded theory",13 but it also permits a great variety of research designs (fully inductive,

\footnotetext{
13 The grounded theory stems from the idea that the theory itself is in the research data, where information relating to the phenomenon under study can be found (Álvarez-Gayou, 2003).
} 


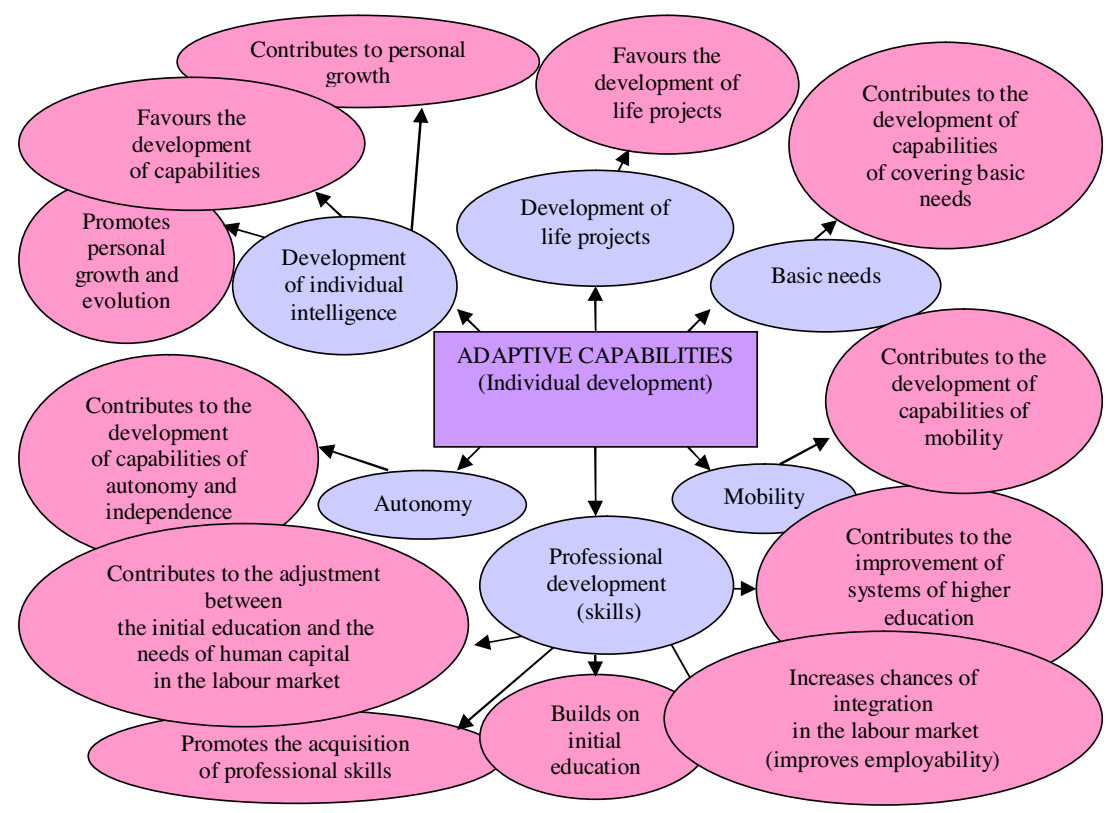

Fig. 4. New capabilities (from the area of "adaptive capabilities") in the form of benefits associated with the Erasmus programme drawn from the sample. Source: prepared by the authors.

deductive or mixed approaches). Specifically, the most important thing about this research aid is that it constitutes a very useful tool for categorizing documents or digitalized data sources. In the present investigation, once the texts were compiled they were converted into formats which were compatible with NVIVO (for example, "doc" documents) and the information was then classified based on the categorical system generated by the team (who had previously been introduced to the software). In short, all the work of categorization and analysis of the information based on relations, comparisons, etc., has been carried out using this software.

\section{Results and discussion}

In order to display the results, new categories drawn from the analysis of collected information (sample) will be presented.

In Fig. 4, new capabilities arising from the information itself and framed in each of our initial capabilities from the "adaptive capabilities" area are collected. As can be seen, the new categories are those which appear in a lighter colour, representing a higher level of specification as regards the initial map.

These new capabilities appear in the text with different levels of representation. Stemming from this diversity, results are displayed which are related to the comparison between agents in their contribution to said categories (Fig. 5). Here, given that we are speaking of comparisons, only information codified as spontaneous (as described in the section corresponding to the design of the investigation) has been used; this represents about $50 \%$ of the total volume of the sample. Following on from these spontaneous contributions it is possible to focus attention on the benefits which are usually referred to when agents talk about the programme, without delimiting the thematic area or previously influencing the typology of benefits.

In Fig. 5, for example, it is possible to observe a significant overlap of agents in the majority of the categories which indicates that all three groups have referred to the majority of capabilities expounded, thus coinciding in the same topics. Moreover, it should be noted that all categories remain present despite not being asked about directly, which means that when the sample drawn from the questionnaires is incorporated, extra categories belonging to said area do not appear (despite the fact that specific questions are asked about this area).

Finding so many similarities between different agents, and between both spontaneous and motivated information, gives rise to a series of reflections. Firstly, it is possible to identify a certain consensus that Erasmus contributes to the enhancement of aforementioned capabilities, even before such aspects are enquired into. Moreover, it seems that agents refer to those elements which are typically spoken about in the Erasmus context-in other words, they are responding to the idea of "what is supposed to be the contribution of the Erasmus programme" based on its area of intervention and principal objectives. Although we do not supply data from other areas of capabilities in this article, we can confirm that in the other areas mentioned, the opposite effect often occurs: many categories of spontaneous information which stand out in the overall sample (where motivated information is integrated) for the importance given to them by agents (questionnaire participants) disappear when we ask about said categories specifically.

Since the behaviour of categories in the area of "adaptive capabilities" has now been summarized, and in order to go more in-depth into the whole process of the original investigation, we're going to have a closer look at one of the new capabilities which, in this case, is present in the contributions of the different agents and which shows itself to be one of those most often referred to.

To describe the presence of said category, we present a table specifying the contribution of each of these agents (Table 1). This information is useful for seeing how much each group refers to these aspects based on the number of references and their distribution among the cases. This last indicator is especially relevant when speaking of participants in the scholarships and coordinators of the programme, given that the "cases" enable us to observe the extent of the overlap among those who make up a group. In short, what is required is to show who refers to said category and how frequently. 


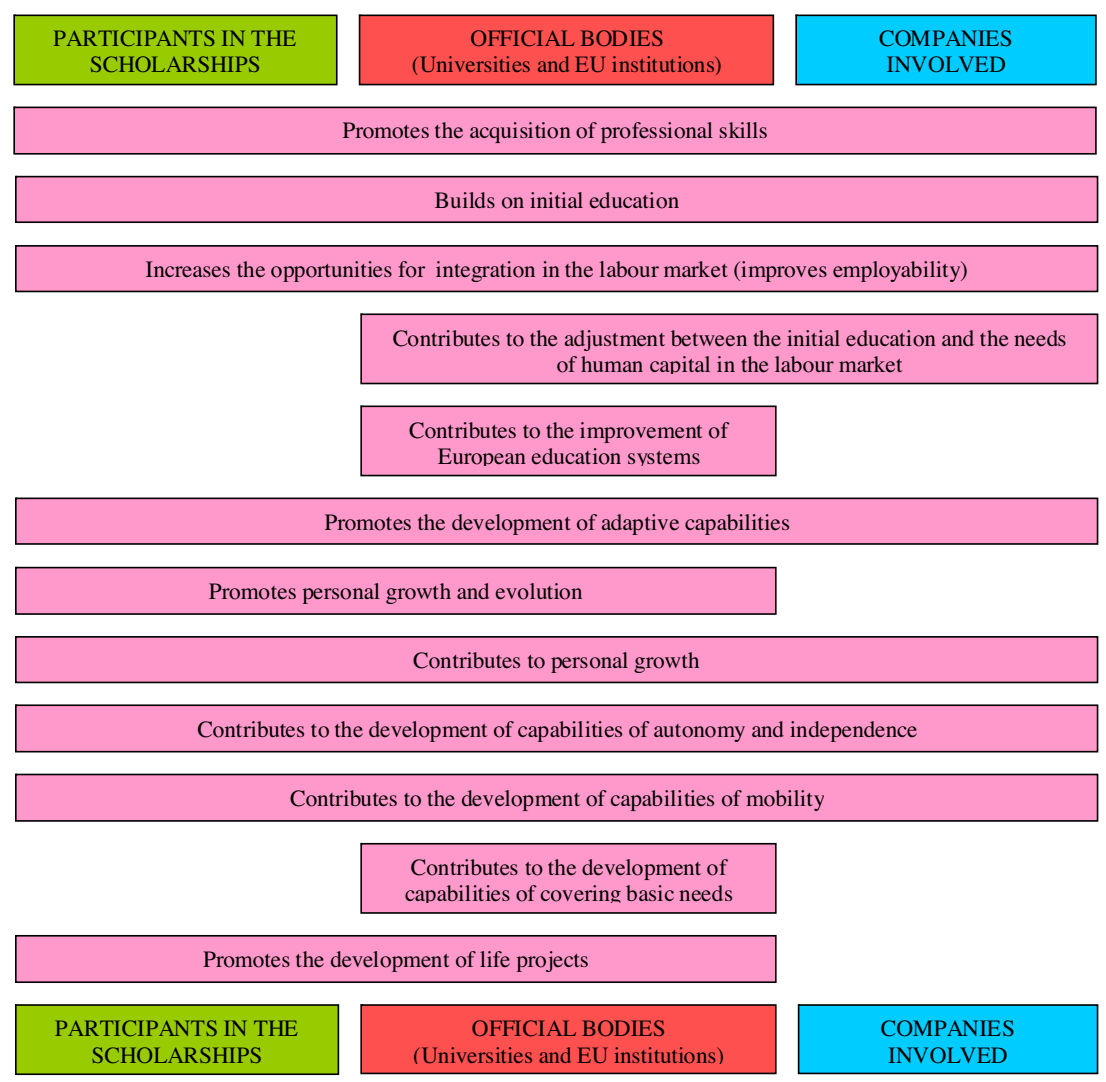

Fig. 5. Spontaneous contribution of the different agencies to the categories of the area of "adaptive capabilities". Source: prepared by the authors.

Given that the NVIVO 10 programme enables us to maintain the textual references listed in this category, we will now provide some examples in which this category is present. It should be noted here that we are speaking of results from the overall sample, keeping in mind that we are no longer establishing comparisons between agents based on spontaneous benefits:

A11 (Participant in the scholarship belonging to LLP). Motivated reference: "Getting on in another country with a different culture has helped me a great deal. Making a life for myself, learning other languages. Judging from my experiences of interviews, time spent abroad is valued extremely highly."

Representatives of Spanish universities in $R E$ magazine: "working as a team, speaking other languages, taking on responsibilities, moving nationally and internationally and being prepared to face unfamiliar environments."

Representatives of participating companies in $R E$ magazine: "autonomy and multidisciplinary skills; a familiarity with teamwork and with working in an international environment; people skills; knowledge of new cultures and exposure to different outlooks on social living."

With regards the criteria followed when selecting information about this specific category, it should be specified that we're talking about references in which the provider of the text showed explicitly that he or she was referring to skills or benefits valued in career and/or professional development; or references which, due to the context of the question (in the case of questionnaires) or the passages in which they were made (in the case of texts), were understood to be referring to this career/professional environment. Following on from here, if we look at the presence of said category, it can be concluded that this is a capability with a high number of references and a wide distribution among agents and participants. From this it can be interpreted that there exists a general view, among the agents involved and the different cases that make up the groups, that the Erasmus experience greatly promotes the acquisition of professional skills which are valued in today's job market.

Aside from analysing the appearance of this capability, and given that it represents one of the categories with the most general statements (to which very different expressions and meanings are attributed), Fig. 6 displays a summary of these meanings. In order to draw it up, the literal definition of the expression has been respected in the majority of cases (as it was expressed by the person or entity in question).

The interesting thing about this category resides in the fact that the majority of contributions are related directly to Senian capabilities. As can be observed, many of the concepts and ideas represent extensions of the possibilities for choice of the individuals themselves, as well as freedoms in areas of decision, self-management, communication, people skills, and environments for individuals to develop their own lives and so on. In short, this is a category which helps give us a clear understanding of how the studied agents perceive the influence of the Erasmus experience as regards the acquisition of capabilities in the form of individual freedoms (from the area of adaptive capabilities).

Furthermore, if we bear in mind that all these expressions are associated directly with the Erasmus experience, we can say that a surprising number of benefits appear which transcend the responsibilities and objectives stated in the regulatory documentation of the programme. 
Table 1

Origin of the references of the category: "Promotes the acquisition of professional skills". ${ }^{15}$

LLP: Lifelong Learning Programme RE: Recruiting Erasmus (magazine).

\begin{tabular}{|c|c|c|c|c|}
\hline Category & \multicolumn{4}{|c|}{ Agents and distribution of references. } \\
\hline \multirow{12}{*}{$\begin{array}{l}\text { Promotes the acquisition of professional skills } \\
\text { Belongs to: "Professional development (skills)" }\end{array}$} & \multirow[t]{4}{*}{ Participants in scholarships. } & \multirow{2}{*}{\multicolumn{2}{|c|}{ Socrates II }} & Cases: $9(90 \%)$ \\
\hline & & & & References: 14 \\
\hline & & \multirow{2}{*}{\multicolumn{2}{|c|}{ LLP }} & Cases: $5(50 \%)$ \\
\hline & & & & References: 8 \\
\hline & \multirow[t]{6}{*}{ Promoting bodies } & \multirow[t]{4}{*}{ Universities } & Coordinators & Cases: $9(90 \%)$ \\
\hline & & & & References: 15 \\
\hline & & & Websites & References: 0 \\
\hline & & & RE Articles & References: 9 \\
\hline & & \multirow[t]{2}{*}{ EU institutions } & Websites & References: 0 \\
\hline & & & RE Articles & References: 0 \\
\hline & \multirow[t]{2}{*}{ Companies } & \multicolumn{2}{|c|}{ RE promoting company } & References: 3 \\
\hline & & \multicolumn{2}{|c|}{ Companies involved } & References: 28 \\
\hline
\end{tabular}

LLP: Lifelong Learning Programme RE: Recruiting Erasmus (magazine).Source: prepared by the authors.

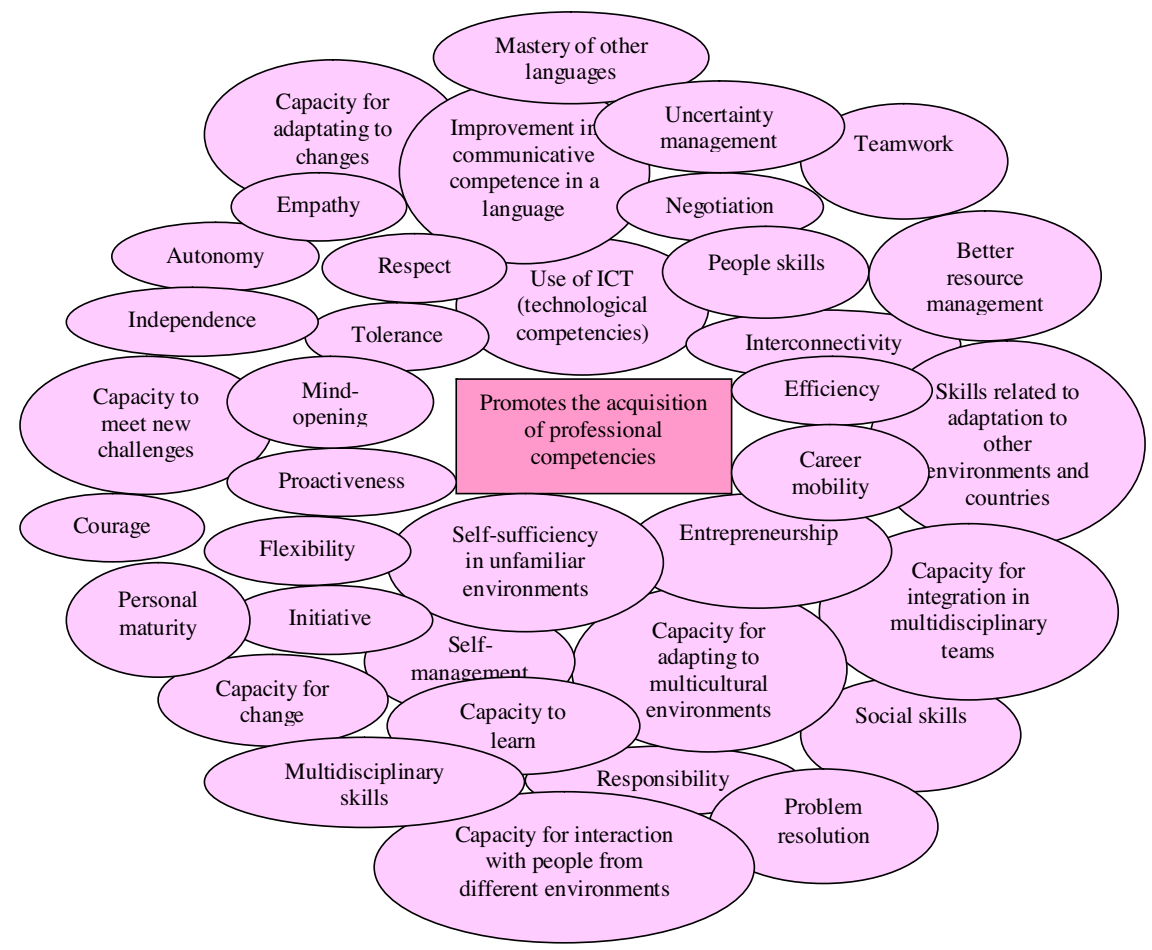

Fig. 6. Concepts and expressions based on the category: "Promotes the acquisition of professional skills.".

Source: prepared by the authors.

\section{Final conclusions. The capacitating power of Erasmus for human development}

As anticipated, evidence of a great capacitating power associated with the Erasmus programme has been found. It can be stated that there is a widespread perception shared by a variety of agents that this programme promotes the development of capabilities as regards adaptation of participants to different environments, the development of skills suited to the labour market, the increase in opportunities for employment and a broadening in the range of options for life projects. Evidence has been found that this experience increases opportunities and choices, thus increasing much-valued freedoms for participants on their paths to developing their lives. In essence, it contributes to individual empowerment by increasing the freedoms of each participant (especially in relation to the possibilities for adaptation to an environment and to an expansion in the diversity of potential environments).
This leads us to consider that, taking into account the evolution of the Erasmus programme, its growth and its scope in terms of ties of cooperation; it could become a strategic platform for the promotion of human development. In the same way as this network is being used to drive the European Higher Education Area and put this education to the service of the knowledge economy, ${ }^{14}$

\footnotetext{
14 A concept which has been introduced following the conclusions of the European Council in Lisbon in March 2000, in which the goal for 2010 was centred on transforming the European brand into the most competitive and dynamic knowledge-based economy in the world.

${ }^{15}$ In the process of constructing the theoretical model presented in the previous sections, it was decided to include the term skills as a concept of greater specificity, integrated, therefore, within one of the areas of capabilities. But it should be made clear that said term is valued here in terms of capabilities, like many others which have been adhered to. The "skills" here are abilities which are germane to the work and professional environment required at this time by the context, and which are therefore relevant to the expansion of capabilities of a person who lives in said environment and who wishes to pursue a career within it.
} 
we believe it could be a highly suitable platform for working towards human development and empowering people. This would imply certain modifications, such as incorporating objectives geared towards the development of capabilities, or the integration of evaluative indicators which are related to capabilities development. In conclusion, one could say that this is a very effective initiative-one that seems to be achieving many of its objectives and which, it should be recognized by this study, seems to be contributing greatly to human development without having being planned explicitly in such terms.

Another aspect of these conclusions is related to the limitations revealed by the study. It's worth bearing in mind that in the case in question, rather than dealing with empirical evidence contrasted in quantitative sample parameters, we examine the perceptions of the different agents involved and a qualitative sample which sacrifices scope in favour of going deeper into the subjectivities of individuals. It should therefore be made clear that in many cases it cannot be conclusively confirmed that the programme causes the given effects. However, these results bring an overview of relevant aspects from the perspective of human development (in this case, regarding "adaptive capabilities"). Furthermore, the results are based on research experience developed from the foundations of the capabilities approach itself (in terms of purpose and form) and thereby contribute to the development of the approach in the area of educational research.

Another conclusion reached is that the results provide extensive information about how the Erasmus experience and its effects are conceived by participants, promoting agents, managers and other implicated parties. Thus, these results contribute to the growth in knowledge about the Erasmus programme itself and the part it plays in the environment in which it operates. This enables us to interpret how official perspectives, and the benefits of the programme as presented by promoting bodies, often focus on certain aspects while forgetting about others which are, nonetheless, greatly valued by the participants and direct observers, and which have great significance from the point of view of human development.

Finally, this study provides a significant source of information which facilitates, in accordance with the idea of a good information base (Sen, 1999a), participation in the public debate which should exist regarding investment in educational initiatives for citizens who contribute to the development of their countries with their taxes. With the targeted information, we are also providing a structured overview which assists in an analysis of the Erasmus phenomenon in its role as a capacitator of citizens and this, in turn, promotes better powers of judgement regarding the aforementioned theme. The study increases our freedoms in the sense that it increases our capacity to understand, express opinions about, make proposals regarding, or criticize the Erasmus initiative (Watene, 2013; Nussbaum, 2015).

\section{References}

Álvarez-Gayou J.L., 2003. Cómo hacer investigación cualitativa. Fundamentos y metodología. (How to do qualitative research. Bases and methodology). Paidós, Barcelona.

Aguaded, J.I., Pozo, C., 2009. Los alumnos Erasmus en la Torre de Babel. El aprendizaje de lenguas extranjeras basado en las competencias comunicativas y en el uso de las TIC. (Erasmus students in the Tower of Babel. Foreign language learning based on communicative competences and the use of ICT). Revista Electrónica Teoría de la Educación. Educación y Cultura en la Sociedad de la Información 10, 310-337.

Alfranseder, J., Escrivá, J., Fellinger, A., Haley, A., Nigmonov, A., Taivere, M., 2012. Exchange, Employment and Added Value. Research Report of the ESN Survey 2011. Erasmus Student Network AISBL (Retrieved on July 20, 2013 from: http:// www.esn.org/sites/default/files/esnsurvey2011_web.pdf).

Alonso, L.E., Fernández, C.J., Nyssen, J.M., 2009. El debate sobre las competencias. Una investigación cualitativa en torno a la educación superior y el mercado de trabajo en España. (The discussion about competences. A qualitative study on higher education and the job market in Spain). Agencia Nacional de Evaluación de la Calidad y Acreditación, Madrid.

Barbour, R., 2013. Los grupos de discusión en investigación cualitativa. (Focus groups in qualitative research). Morata, Madrid.

Barone, S., Mella, P., 2003. Acción educativa y desarrollo humano en la universidad de hoy. (Educational action and human development at university today). Revista Iberoamericana de Educación 31, 187-219.

Boni, A., Walker, M., 2013. Human Development and Capabilities. Routledge, New York.

Boni, A., Lozano, J.F., Walker, M., 2010. La Educación Superior desde el enfoque de capacidades. Una propuesta para el debate. (Higher Education from the capabilities' approach. A proposal for discussion). REIFOP 13, 123-131.

Cejudo, R., 2006. Desarrollo humano y capacidades. Aplicaciones de la teoría de las capacidades de Amartya Sen a la educación. (Human development and capabilities. Applications of Amartya Sen's theory of capabilities to education) Revista Española de Pedagogía 234, 365-380.

Clark, D.A., Fennell, S., 2014. Democratic freedoms, capabilities and public provision: a defence and some possible extensions. J. Hum. Dev. Capabilities A Multi Discip. J. People Centered Dev. 15, 437-447. doi:http://dx.doi.org/10.1080/ 19452829.2014.967524.

DeCesare, T., 2014. Theorizing democratic education from a senian perspective. Stud. Philos. Educ. 33, 149-170.

Demerath, P., 2006. The science of context: modes of response for qualitative researchers in education. Int. J. Qual. Stud. Educ. 19 (1), 97-113.

Deneulin, S., Townsend, N., 2006. Public goods, global public goods and de common good. Int. J. Soc. Econ. 34, 19-36.

Denzin, N.K., Lincoln, Y.S., 2012. Manual de investigación cualitativa. Volumen I. El campo de la investigación cualitativa. (Qualitative research manual. Volume I. The field of qualitative research). Gedisa, Barcelona.

Dubois, A., 2008. El debate sobre el enfoque de las capacidades: las capacidades colectivas. (The discussion on the approaches to capabilities: collective capabilities). Araucaria 10, 35-63.

EURYDICE (2012). Cifras clave de la educación en Europa 2012. (Key numbers in European education 2012). Eurydice, Brussels 10.2797/86046.

European Commission, 2010. Communication from the Commission of 3 March 2010 - Europe 2020 A strategy for smart, sustainable and inclusive growth. COM (2010) 2020 final -(Not published in the Official Journal). Retrieved on May 20, 2014 from: http://eurlex.europa.eu/LexUriServ/LexUriServ.do? uri=COM:2010:2020:FIN:ES:PDF.

European Commission, 2014. The Erasmus Impact Study. Effects of mobility on the skills and employability of students and the internationalisation of higher education institutions. Publications Office of the European Union, Luxembourg $10.2766 / 75468$.

European Council, 2010. The Lisbon Special European Council: towards a Europe of Innovation and Knowledge. . Eur-Lex c10241. Retrieved on May 20, 2014 http:// eur-lex.europa.eu/legal-content/EN/TXT/?url=uriserv\%3Ac10241.

European Council (2013). Council Conclusions on investing in education and training $-\mathrm{a}$ response to 'Rethinking Education: Investing in skills for better socio- economic outcomes' and the '2013 Annual Growth Survey'. Diario Oficial de la Unión Europea, serie C, $n^{\circ}$ 64/6 de 5 de marzo de 2013.

Fernández, S., Pérez, C., Vaquero, A., 2009. Movilidad internacional de la Universidad Española: Análisis regional e institucional del programa Sócrates-Erasmus. (International mobility in Spanish universities: regional and institutional analysis of the Socrates-Erasmus programme). Revista de Estudios Regionales $85,143-172$

Fernández, M., 2010. La movilidad: sello distintivo del Espacio Europeo de Educación Superior. (Mobility: the hallmark of the European Higher Education Area). Revista de Formación e Innovación Educativa Universitaria 3, 112-124.

Flores, P., 2002. La búsqueda de nuevas explicaciones sobre la relación entre educación y desigualdad. El caso de la Universidad Tecnológica de Nezahualc. (The research of new explanations for the relationship between education and inequality. The case of the Technological University of Nezahualc). Revista Mexicana de Investigación Educativa 7, 537-576.

Hans-Uwe, O., Schafer, S., 2014. New Approaches Towards 'The Good Life': Applications and Transformations of the Capability Approach. Barbara Budrich Publishers, Berlin, Toronto.

Huber, G.L., Fernández, G., Lorenzo, O., Herrera, L., 2001. Análisis de datos cualitativos con Aquad cinco para Windows. (Qualitative data analysis with Aquad 5 for Windows). Grupo Editorial Universitario, Granada.

Iacoboni, M., 2009. Las neuronas espejo. Empatía, neuropolítica, autismo, imitación o de cómo entendemos a los otros. Katz Editores, Madrid.

Ibrahim, S., Tiwari, M., 2014. The Capability Approach: From Theory to Practice. Palgrave MacMillan, London.

Kolenic, G.E., 2013. Introduction to NVivo 10. Center for Statistical Consultation and Research (CSCAR). Retrieved on February 1, 2013 from: http://sitemaker.umich. edu/gkolenic/files/nvivo10_winter2013.pdf.

Marina, J.A., 2008. La inteligencia fracasada. Teoría y práctica de la estupidez. (Failed intelligence. Theory and practice of stupidity). Anagrama, Barcelona.

Marina, J.A., 2010. Las culturas fracasadas. El talento y la estupidez de las sociedades. (Failed cultures. Societies' talent and stupidity). Anagrama, Barcelona.

Mutanga, O., 2014. The role of basic education, higher education and capability lists. J. Hum. Dev. Capabilities A Multi Discip. J. People Centered Dev. 15, 448-451. doi: http://dx.doi.org/10.1080/19452829.2014.966967.

Nebel, M., Flores-Crespo, P., Herrera, T., 2014. Desarrollo como libertad en Ame'rica Latina. Fundamentos y aplicaciones. (Development as freedoom in Latin America. Bases and applications). Universidad Iberoamericana, México. 
Nussbaum, M., 1997. Cultivating Humanity. A Classical Defence of Reform in Liberal Education. Harvard University Press, MA.

Nussbaum, M., 1998. Capacidades humanas y justicia social. (Human capabilities and social justice). In: Riechmann, J. (Ed.), Necesitar, desear, vivir. Sobre necesidades, desarrollo humano, crecimiento económico y sustentabilidad. (Need, desire, life. About needs, human development, economic growth and sustainability). Los Libros de la Catarata, Madrid, pp. 43-104.

Nussbaum, M., 2000. Women and Human Development. Cambridge University Press, Cambridge.

Nussbaum, M., 2011. Creating Capabilities. The Human Development Approach. The Belknap Press, Cambridge, MA.

Nussbaum, M., 2015. Philosophy and economics in the capabilities approach: an essential dialogue. J. Hum. Dev. Capabilities A Multi Discip. J. People Centered Dev. 16,1-14. doi:http://dx.doi.org/10.1080/19452829.2014.983890.

Piñuel, J.L., Gaitan, J.A., 2003. La violencia en la escuela a través de la prensa on-line de los periódicos de referencia en España. (School violence through the on-line version of the main newspapers in Spain). Serie Informas-MEC, Madrid.

Piñuel, J.L., Gaitan, J.A., 2004. Agenda y mapa de actualidad en el tratamiento de los medios de comunicación social en relación con la educación. (Agenda and current mapping of the treatment of social media with regards to education). Serie Informas-MEC, Madrid.

Piñuel, J.L., 2002. Epistemología, metodología y técnicas del análisis de contenido. (Epystemology, methodology and techniques in content analysis). Universidad Complutense de Madrid, Madrid.

Pineda, P., Belvís, E., Moreno, M., 2007. La participación de los estudiantes universitarios en programas de movilidad: factores y motivos que la determinan. (Factors and reasons determining university students' participation in mobility programmes). Revista Iberoamericana de Educación 42, 1-14.

Pozo, C., 2011. Las competencias comunicativas interculturales y los usos interactivos de Internet de los estudiantes Erasmus alemanes y españoles. (Intercultural communicative competences and interactive Internet uses in German and Spanish Erasmus students). (PhD Thesis). Universidad de Huelva, Huelva.

Sastre J.J., Boni A., Fernández-Baldor A., Gómez Ll., 2012. Análisis del programa Meridies-cooperación desde el Enfoque de Capacidades. (Analysis of the Meridies-cooperación programme from the capabilities' approach). In: Domínguez, R. (President), I Congreso REEDES. Retrieved on November 6, 2013 from: http://www.upv.es/entidades/CCD/infoweb/ccd/info/U0632114.pdf.

Sen, A., Nussbaum, M., 1993. The Quality of Life. Clarendon Press, Oxford.

Sen, A., 1980. Equality of what? In: Sterling, M. (Ed.), The Tanner Lecture on Human Values. Cambridge University Press, Cambridge, pp. 197-220.

Sen, A., 1995. Nueva economía del bienestar. (New welfare economy). Universidad de Valencia, Servicio de Publicaciones, Valencia.
Sen, A., 1997. Bienestar, justicia y mercado. (Welfare, justice and market). Paidós ICE/ UAB, Barcelona.

Sen, A., 1999a. Nuevo examen de la desigualdad. (New inspection of inequality). Alianza Editorial, Madrid.

Sen, A., 1999b. Development as Freedom. Oxford University Press, Oxford.

Sen, A., 2003. Sobre ética y economía. (About ethics and economy). Alianza Editorial, Madrid.

Sen, A., 2006. El valor de la democracia. (The value of democracy). Ediciones de Intervención Cultural/El Viejo Topo, Barcelona.

Sen, A., 2011. Desarrollo y crisis global. (Development and global crisis). Editorial Complutense S. A., Madrid.

Serbia, J.M., 2007. Diseño, muestreo y análisis en la investigación cualitativa. (Design, sampling and analysis in qualitative research). HOLOGRAMÁTICA 7, $123-146$.

Sommer, B., Sommer, R., 1997. La investigación del comportamiento. (Researching behaviour). Oxford University Press, Méjico.

Strauss, A., Corbin, J., 1990. Basics of Qualitative Research. Grounded Theory Procedures and Techniques. Sage, California.

Valdemoro, M.G., Ponce de León, A., Sanz, E., 2011. Fundamentos en el manejo del NVIVO 9 como herramienta al servicio de estudios cualitativos. (Bases to manage NVIVO 9 as a tool for qualitative studies). Contextos Educativos 14,1129.

Valle, J.M., Garrido, R., 2009. La asimetría en los flujos de movilidad de estudiantes Erasmus. (Asymmetry in Erasmus students' mobility flows). Revista Española de Educación Comparada 15, 93-130.

Valle, J.M., Garrido, R., 2014. Los flujos de movilidad Erasmus al término del programa Lifelong Learning y comienzo del Erasmus +. (Erasmus mobility flows at the end of the Lifelong Learning Programme and the beginning of Erasmus + ). Revista Internacional de Estudios sobre Sistemas Educativos 2, 37-57.

Valle, J.M., 2004. La política educativa de la Unión Europea: fundamentos evolución histórica y propuesta de un modelo para su análisis crítico. (Educational policy in the European Union: bases, historical evolution and proposal of a model for its critical analysis). Revista Española de Educación Comparada 10, 17-59.

Vaughan, R.P., Walker, M., 2012. Capabilities, values and education policy. J. Hum. Dev. Capabilities 13 (3), 495-512. doi:http://dx.doi.org/10.1080/ 19452829.2012.679648.

Walker, M., 2012. A capital or capabilities education narrative in a world of staggering inequalities? Int. J. Educ. Dev. 32, 384-393.

Watene, K., 2013. Nussbaum's capability approach and future generations. J. Hum. Dev. Capabilities A Multi Discip. J. People Centered Dev.14, 21-39. doi:http://dx. doi.org/10.1080/19452829.2012.747488.

Weber, R.P., 1990. Basic Content Analysis. Sage, Newbury Park. 